\title{
Sol piriform sinüse impakte olan nazogastrik tüpün endoskopik yolla çıkartılması
}

\author{
Endoscopic removal of nasogastric tube impacted in the left pyriform sinus \\ Harun ERDAL, Bülent ÇOLAK, Özlem GÜL UTKU, Tarkan KARAKAN, Mehmet IBIŞ \\ Gazi Unniversitesi Tıp Fakültesi, Gastroenteroloji Bilim Dalı, Ankara
}

Yetmiş yaşında erkek hasta sol bukkal adeno kistik karsinoma nedeniyle opere edilmiş. Postoperatif takibinde enteral beslenme amacıyla nazogastrik tüp (NG) takılması planlanmış. İşlem esnasinda nazogastrik tüpün ilerlemediği ve geri çekilmesi ile çıkarılamadığı gözlenmiş. Endoskopik değerlendirme amacıyla kliniğimize refere edilmiş olan hasta değerlendirildi.

Endoskopik incelemede NG tüpün yerleştirilmesi esnasında sol piriform sinüse impakte olduğu aşırı itme nedeniyle nazal kavitede kirllarak ve operasyona sekonder dokudaki lokal ödeme bağlı olarak geriye çekilemediği gözlendi (Resim 1).

Forceps ile mevcut NG tüpün segmenti endoskopik olarak oral yolla çıkartıldı (Resim 2). Kılavuz tel eşliğinde sağ piriform sinus komşuluğundan geçilerek yeni bir NG tüp yerleştirildi (Resim 3).

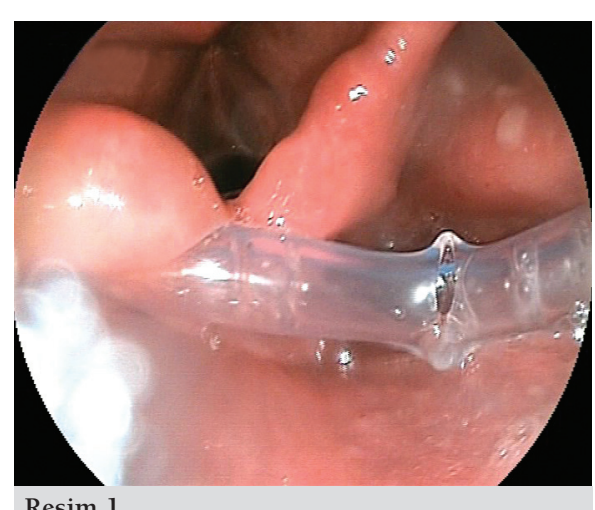

Resim 1

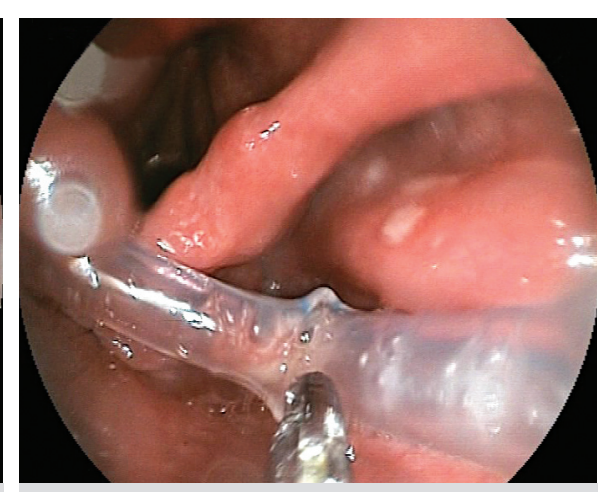

Resim 2.

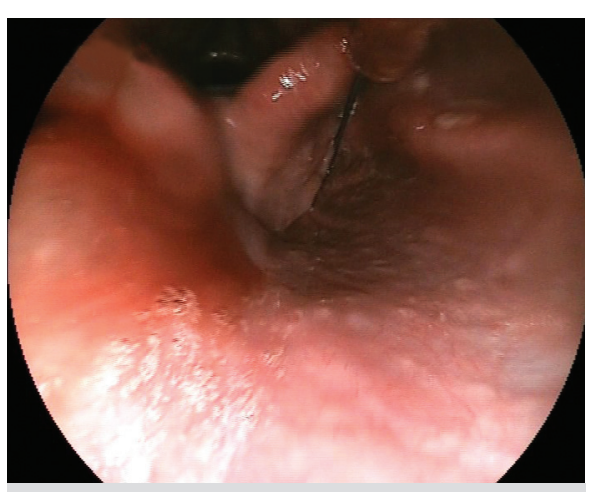

Resim 3.

\section{YORUM:}

Bu olguda benim üzerinde asıl durmak istediğim; nazogastrik tüpün takılmaya çalışılması sırasında sol piriform sinüse saplanmasına neden olacak ölçüde kontrolsüz ve zorlayarak işlemin yapılması, bir diğeri ise genelde yumuşak olan nazogastrik tüpün burun boşluğunda kırılmış olması. Bunları açıklamak oldukça zor. Nazogastrik tüp takarken engelle karşılaşıldığında zorlanmaması, işlemin nazikçe yapılması gerektiğini gösteren bir olgu. Başarılı endoskopik manevra ile de kırılıp içerde kalmış parça kolayca çıkarılabilmiş. 